\title{
Resistance to Epidermal Growth Factor Receptor-Tyrosine Kinase Inhibitors by Transformation to Small Cell Lung Cancer in an EGFR-mutant Patient
}

\author{
EGFR Mutasyonu Olan bir Hastada Küçük Hücreli Akciğer Kanserine \\ Dönüşüm Yoluyla Gelişen Epidermal Büyüme Faktörü Reseptörü-Tirozin \\ Kinaz Inhibitör Direnci
}

Derya Kızılgöz', Pınar Akın Kabalak', Tuba Inal Cengiz' Ülkü Yılmaz', Hatice Esra Özaydın², Özgür Ekinci ${ }^{3}$ Nalan Akyürek ${ }^{3}$ Suna Kavurgacı'

\begin{abstract}
It is important to determine the histological tumor type in non-small cell lung cancer (NSCLC). In patients with adenocarcinoma harboring the epidermal growth factor receptor (EGFR) exon 19 deletion mutation, targeted therapy can yield survival benefit. The epidermal growth factor receptor tyrosine kinase inhibitors gefitinib and erlotinib can provide survival benefit for advanced stage NSCLC patients. However, increasing evidence of acquired resistance to these drugs has been reported, and numerous molecular and biological mechanisms of acquired resistance have been detected. The present report is description of 1, such resistance mechanisms: transformation to small cell lung cancer in a patient who was in the 13th month of erlotinib therapy.
\end{abstract}

Key words: Non-small cell lung cancer, epidermal growth factor tyrosine kinase inhibitors, resistance mechanism, small cell carcinoma transformation.
Özet

Küçük hücre dışı akciğer karsinomunda subtiplendirmenin yapılması önemlidir. Epidermal growth factor reseptör (EGFR) Egzon 19 delesyonuna sahip adenokarsinomlu olgularda, gefitinib ve erlotinib olarak bilinen EGFR-Tirozin kinaz inhibitörü tedaviler ile ileri evre hastalarda sağkalımda fayda elde edilebilmektedir. Ancak birçok moleküler ve biyolojik mekanizmalar ile bu ilaçlara karşı direnç gelişebilmektedir. Bu yazıda, erlotinib tedavisinin 13. ayında, direnç mekanizmalarından biri olan küçük hücreli akciğer kanseri dönüşümünü, bir olgu eşliğinde sunmayı amaçladık.

Anahtar Sözcükler: Küçük hücre dışı akciğer kanseri, epidermal büyüme faktörü tirozin kinaz İnhibitörleri, rezistans mekanizmaları, küçük hücreli akciğer kanseri dönüşümü.
'Department of Chest Disease, Ankara Atatürk Chest Disease and Thoracic Surgery Training and Research Hospital, Ankara, Turkey ${ }^{2}$ Department of Pathology, Ankara Atatürk Chest Disease and

Thoracic Surgery Training and Research Hospital, Ankara, Turkey ${ }^{3}$ Department of Pathology, Gazi University Faculty of Medicine, Ankara, Turkey
'Ankara Atatürk Göğüs Hastalıkları ve Göğüs Cerrahisi Eğitim Araştırma Hastanesi, Göğüs Hastalıkları Anabilim Dalı, Ankara

${ }^{2}$ Atatürk Göğüs Hastalıkları ve Göğüs Cerrahisi Eğitim Araştırma Hastanesi, Patoloji Anabilim Dalı, Ankara

${ }^{3}$ Gazi Üniversitesi Tıp Fakültesi, Patoloji Anabilim Dalı Ankara

Submitted (Başvuru tarihi): 25.01.2017 Accepted (Kabul tarihi): 13.03.2017

Correspondence (iletişim): Derya Kızılgöz, Department of Chest Disease, Ankara Atatürk Chest Disease and Thoracic Surgery

Training and Research Hospital, Ankara, Turkey

e-mail: derya.ozaydin999@gmail.com

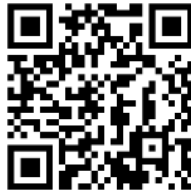


The ErbB family of proteins, and includes 4 different tyrosine kinase receptors: EGFR, ErbB-2, ErbB-3, and ErbB-4. They are activated in human carcinomas when an EGFlike peptide binds to an EGF receptor. EGFR plays a major role in tumor growth. Following EGFR signaling, many other angiogenic proteins are secreted into the tumor micro-environment, which may facilitate growth and metastasis of cancer tissue (1). EGFR may be overexpressed in many epithelial cancers, including NSCLC.

Some somatic deletions on the EGFR gene lead to amplified EGFR copies and worsen the prognosis (2). An L858R point mutation and the exon 19 deletion are the most frequently seen EGFR mutations (3). EGFR-tyrosine kinase inhibitors (TKIs) are used as targeted therapy in patients with NSCLC who have an active EGFR mutation. Erlotinib and gefitinib are first generation EGFR-TKIs drugs, and provide progression-free survival. The best response to these drugs is obtained in patients who are of Asian race, female gender, non-smokers, and have adenocarcinoma $(4,5)$. A significantly greater response rate and progression-free survival can be obtained with first generation EGFR-TKIs in first-line treatment than with platinum-based chemotherapy in EGFR-mutated NSCLC. But overall survival does not differ. The most common adverse effects of EGFR-TKIs are dry skin, diarrhea, skin rash, and elevated serum transaminases. According to studies investigating EGFR-TKIs in elderly patients with NSCLC, it has been reported that erlotinib and gefitinib may be considered as first-line treatment since the side effects are less serious and the drugs are generally well tolerated. There is no significant contribution to clinical response using EGFR-TKIs in combination with standard chemotherapy regimens (6).

Although they have great clinical efficacy, primary or acquired resistance is inevitable. There are currently limited data about primary resistance. The coexistence of a T790M mutation with exon 19 deletion, BIM deletion polymorphism, and mesenchymal-epithelial transition (MET) amplification, are the pathways most suspected in primary resistance (7). EGFR T790M substitution, MET and ERBB2 gene amplification, overexpression of hepatocyte growth factor, down regulation of phosphatase and tensin homolog (PTEN) and transformation to SCLC are well-defined pathways of acquired resistance usually seen between months of 9 and 14 of EGFR-TKI treatment (8). In this instance afatinib and dacomitinib, second generation EGFR-TKIs, which bind irreversibly to EGFR receptors, may be considered as targeted therapy for patients who have resistance to first-line EGFR-TKIs $(9,10)$. T790M is the most common secondary mutation and it prevents binding of first-line EGFR-TKIs to receptors, but afatinib can block the adenosine $5^{\prime}$-triphosphate-binding site of a tyrosine kinase receptor and the cancer cell goes to apoptosis (6). According to the LUX-Lung 1 study comparing afatinib to a placebo in patients with acquired resistance to first-line EGFR-TKIs, afatinib was superior to placebo in terms of median progression-free survival and response rate (11).

SCLC transformation in patients with adenocarcinoma is rarer than other resistance mechanisms; fewer than 30 cases have been reported so far. There are some reports demonstrating the importance of a PTEN M2641 mutation and the PI3K-AKT pathway in SCLC transformation, but these molecular anomalies do not suffice to explain the mechanism; hence, the subject is still unclear (8).

Presently described is the case of an NSCLC patient with mutant EGFR developing SCLC transformation in the 13th month of EGFR-TKI treatment, and a review of the literature.

\section{CASE}

A 59-year-old male who was a non-smoker with chronic cough was referred to the hospital due to suspected lung cancer. Chest $\mathrm{X}$-ray revealed pleural effusion in the left hemithorax, and diagnostic thoracentesis was performed (Figure 1d). Based on the cell-block examination, the diagnosis was metastasis of lung adenocarcinoma with thyroid transcription factor-1 (TTF-1) positivity. 18FFluorodeoxyglucose-positron emission tomographycomputed tomography (18F-FDG PET-CT) revealed a $2.9 \times 2.5 \mathrm{~cm}$ mass on the left lung apical lobe with maximum standardized uptake value (SUV-max) of 12.3, $4.3 \times 3.3 \mathrm{~cm}$ aorta-pulmonary lymphadenopathy with SUVmax of 13.9, locally increased FDG uptake in the left parietal pleura, hypermetabolic lesions in the left surrenal gland (SUV-max: 15.4), and multiple bone metastases, including left ischium and neck of femoral bone (Figure $1 a, b$, and c). The patient underwent first-line chemotherapy with 4 cycles of cisplatin-gemcitabine followed by palliative radiotherapy at 2000 centigray in 5 fractions to an existing lytic lesion causing pain on the left hip. Pleural effusion and lesion on the left upper lobe demonstrated partial response, according to the Response Evaluation Criteria in Solid Tumors criteria (Figure 1e). 


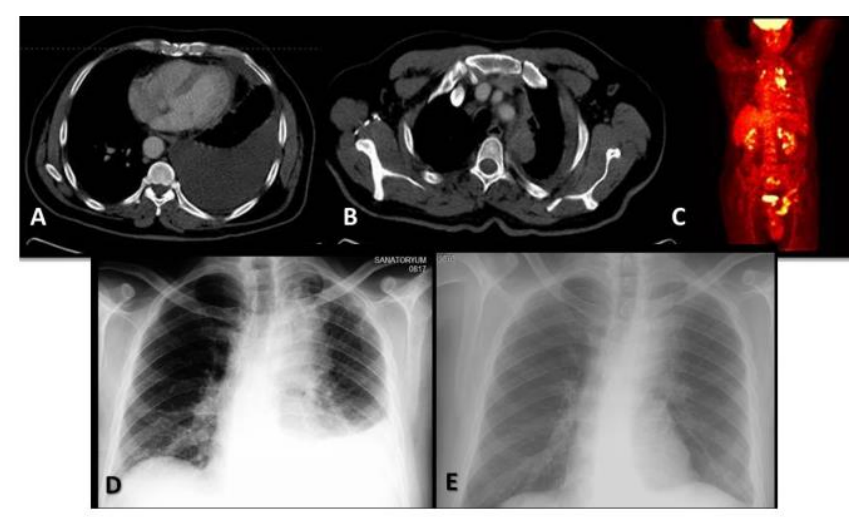

Figure 1a, b, c, d, and e: Left apical mass with ipsilateral pleural effusion and multiple bone metastases ( $a, b, c)$, Chest X-ray demonstrates left hilar enlargement and left pleural effusion (d), Regression of pathological findings illustrated on chest X-ray after 4 cycles of cisplatingemcitabine (e)

In the second month of follow-up, the patient was admitted with dyspnea. CT of thorax revealed progression of the primary lesion and newly formed pleural effusion in the left hemithorax (Figure $2 a$ and b). He had EGFR exon 19 deletion, so EGFR-TKI therapy of erlotinib 150 $\mathrm{mg} /$ day was initiated as second-line treatment. There was good radiological response seen on CT performed in ninth month of erlotinib therapy (Figure $2 c$ and $d$ ). In the 13th month of EGFR-TKI treatment, disease progressed in both the primary lesion and metastatic sides, according to results of 18F-FDG PET-CT (Figure 3a), so 5 cycles of pemetrexed-cisplatin were administered as third-line chemotherapy. After the latest session, the mass in the left apical lobe progressed (Figure $3 b$ and c) again and rebiopsy was performed with transthoracic fine needle aspiration (TTFNA). His new pathological diagnosis was, surprisingly, high-grade neuroendocrine carcinoma combined with SCLC (Figure 3d). Following standard procedures, DNA obtained using a cobas DNA sample preparation kit (Roche Molecular Systems, Inc., Pleasanton, CA USA) from the biopsy was analyzed using the cobas EGFR mutation test (Roche Molecular Systems, Inc., Pleasanton, CA, USA), and direct sequencing and EGFR exon 19 deletion were identified. But no other mutation, including T790M, was detected. After 2 cycles of cisplatinetoposide there was minimal radiological response, but his medical condition worsened and he could not continve chemotherapy. The patient died while in a supportive care program, 23 months after the beginning the therapy.

\section{DISCUSSION}

At present, EGFR-TKls can provide remarkable tumor regression in NSCLC patients who have somatic EGFR exon mutations. However, acquired or secondary re- sistance to EGFR-TKIs is inevitable. Some alternative treatment options are currently available, depending on the resistance mechanisms (8). But the main dilemma lies in how to assess in which patient EGFR-TKI resistance may develop and for which patient to do a re-biopsy. According to the relevant literature, the criteria to expect a probable secondary TKI resistance are single-agent treatment with EGFR-TKI for EGFR mutations and related drug sensitivity, systemic progression under TKI treatment, and other systemic chemotherapies after cessation of TKIs (12). However most often, the responsibility for TKI resistance lies in particular mutations, overexpression of growth factors, amplification of some oncogenes, histopathological transformation to SCLC, and squamous cell cancer and NSCLC with neuroendocrine morphology (13, $14,15)$.

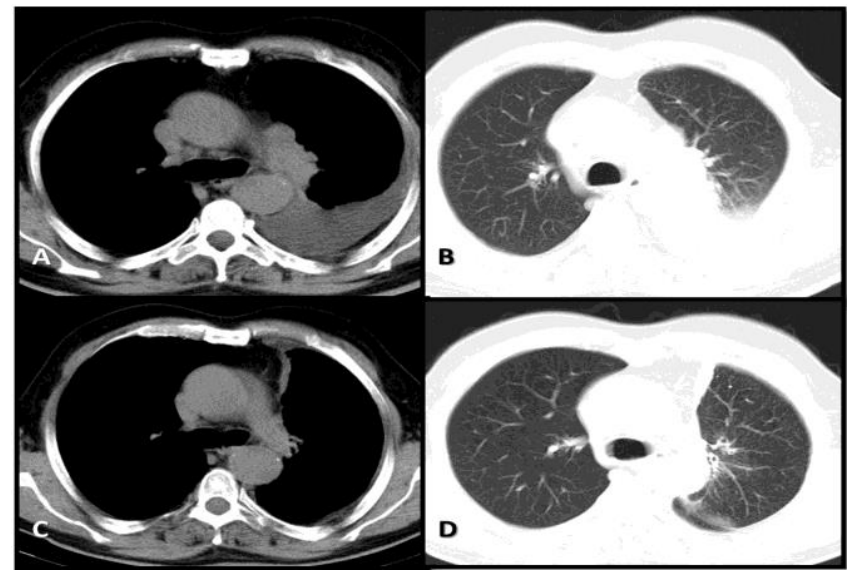

Figure 2a, b, c, and d: Progression of primary lesion before erlotinib treatment $(a, b)$, Radiological response in the ninth month of erlotinib treatment $(c, d)$

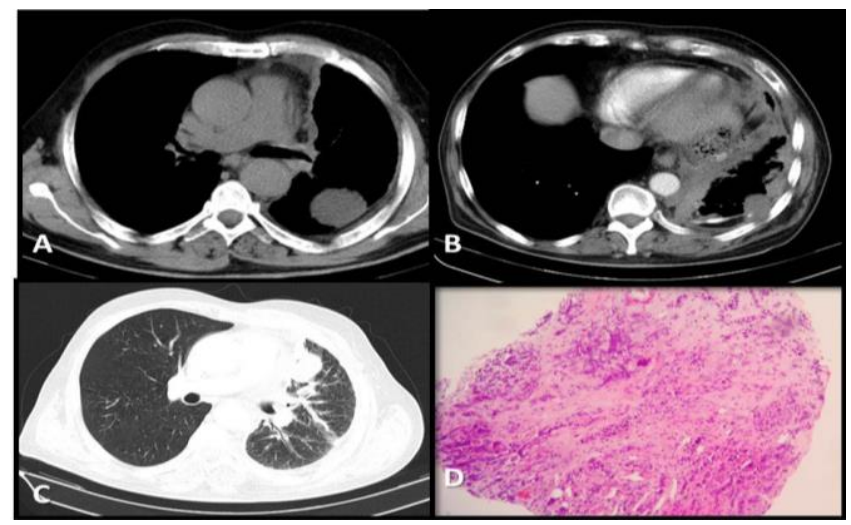

Figure $3 a, b, c$, and d: Left apical sub pleural mass showing progression in the 13th month of erlotinib treatment (a), Multiple, newly developed nodules on the left lung after 5 cycles of sisplatin-pemeterexed. $d$ : Re-biopsy specimen showing small cell lung cancer $(b, c)$

SCLC transformation is relatively rare. In previous reports, most of the patients were female and were diagnosed in the fourth or fifth decade of life. But there are not enough 
data to comment on age or gender predominance. The present case is a male and was in his sixth decade. Patient smoking habits weren't mentioned in any of the prior reports; however, some cases did not have a history of smoking. In our patient, diagnosis was obtained from pleural cytological analyses. Synchronous tumor was excluded due to response of both pleural effusion and left upper lesion to platinum-based chemotherapy and erlotinib. Overall survival is less than 6 months for an SCLC patient without treatment (19). In the current case, it was nearly 16 months to second progression.

Acquired resistance is mostly seen after 9 to 14 months of EGFR-TKI therapy (8). Similarly, in the present case, tumor progression occurred in the 13th month of erlotinib therapy. SCLC transformation is mostly seen with the genotype Exon 19 deletion or L858R, which are sensitive to EGFR-TKI therapy (16). Similarly, in present case, while the SCLC specimen was positive for exon 19 deletion, it was negative for a T790M mutation. There are several opinions about the underlying mechanisms of SCLC transformation in EGFR-mutation patients in autopsy and genotype studies. In a study analyzing 122 SCLC patients in terms of EGFR mutation, it was detected in only 5 (4\%) patients. Combined histopathology with adenocarcinoma was notable in these patients. Both SCLC and adenocarcinoma subtype harbored EGFR mutations, but only the adenocarcinoma component had gene amplification. Investigators reported partial response with gefitinib in an EGFR-mutant SCLC patient (17). In clinical practice, perhaps, since the beginning of treatment both histopathological types are present. It can be explained by tumor heterogeneity, but it's difficult to detect this combined histopathology using small biopsy specimens. Our patient was first diagnosed with cytoblock examination, and SCLC was diagnosed with TTFNA.

Another possible explanation for acquired resistance to TKIs is phenotypic transformation. Under first-line EGFRTKI treatment, changes in gene amplification may lead to prominence of the existing SCLC component. In this instance, some specific genomic changes may have a role in SCLC transformation. In a patient with EGFR mutation, while liver metastasis showing SCLC phenotype had PTEN M2641, metastasis of adenocarcinoma phenotype didn't have this mutation (8). Sequist et al. (18) reported a PI3KAKT mutation with SCLC transformation, but a presence of only $5 \%$ of NSCLC cases. Therefore, both mutations are not specific to SCLC. In the present case, PTEN M2641 and PI3K-AKT mutations were not studied. In short, the SCLC transformation mechanism is still unclear.
Currently, there is no algorithm for how to manage SCLC transformation. The efficacy of standard chemotherapy regimens is unclear. Watanabe et al. reported partial response with carpoplatin-etoposid in a patient with SCLC transformation (16). In our case, 2 cycles of cisplatinetoposide were administered with partial radiological response, but the treatment had to be discontinued due to the patient's poor medical condition.

In conclusion, due to the possible benefit of standard cytotoxic agents against SCLC transformation, clinicians shouldn't hesitate to re-biopsy in the case of progression under EGFR-TKI therapy.

\section{CONFLICTS OF INTEREST}

None declared.

\section{AUTHOR CONTRIBUTIONS}

Concept - D.K., P.A.K., T.I.C., Ü.Y., H.E.Ö., Ö.E., N.A., S.K.; Planning and Design - D.K., P.A.K., T.I.C., Ü.Y., H.E.Ö., Ö.E., N.A., S.K.; Supervision - D.K., P.A.K., T.I.C., Ü.Y., H.E.Ö., Ö.E., N.A., S.K.; Funding - P.A.K.; Materials - D.K.; Data Collection and/or Processing Ü.Y.; Analysis and/or Interpretation - T.I.C.; Literature Review - S.K.; Writing - D.K.; Critical Review - P.A.K.

\section{YAZAR KATKILARI}

Fikir - D.K., P.A.K., T.I.C., Ü.Y., H.E.Ö., Ö.E., N.A., S.K.; Tasarım ve Dizayn - D.K., P.A.K., T.I.C., Ü.Y., H.E.Ö., Ö.E., N.A., S.K.; Denetleme - D.K., P.A.K, T.I.C., Ü.Y., H.E.Ö., Ö.E., N.A., S.K.; Kaynaklar - P.A.K.; Malzemeler - D.K.; Veri Toplama ve/veya İşleme - Ü.Y.; Analiz ve/veya Yorum - T.I.C.; Literatür Taraması - S.K.; Yazıyı Yazan - D.K.; Eleştirel İnceleme - P.A.K.

\section{REFERENCES}

1. De Luca A, Carotenuto A, Rachiglio A, Gallo M, Maiello $M R$, Aldinucci $D$, et al. The role of the EGFR signalling in tumour microenvironment. J Cell Physiol 2008; 214:559-67. [CrossRef]

2. Amann J, Kalyankrishna S, Massion PP, Ohm JE, Girard $L$, Shigematsu $\mathrm{H}$, et al. Aberrant epidermal growth factor receptor signalling and enhanced sensitivity to EGFR inhibitors in lung cancer. Cancer Res 2005; 65:226-35.

3. Sharma SV, Bell DW, Settleman J, Haber DA. Epidermal growth factor receptor mutations in lung cancer. Nat Rev Cancer 2007; 7:169-81. [CrossRef]

4. Maemondo M, Inove A, Kobayashi K, Sugawara S, Oizumi $\mathrm{S}$, Isobe $\mathrm{H}$, et al. Gefitinib or chemotherapy for 
non-small-cell lung cancer with mutated EGFR. N Engl J Med 2010; 362:2380-8. [CrossRef]

5. Zhou $C, W u Y L$, Chen $G$, Feng J, Liu $X Q$, Wang $C$, et al. Erlotinib versus chemotherapy as first-line treatment for patients with advanced EGFR mutation-positive nonsmall-cell lung cancer (OPTIMAL, CTONG-0802): a multicentre, open-label, randomised, phase 3 study. Lancet Oncol 2011; 12:735-42. [CrossRef]

6. Asami K, Atagi S. Epidermal growth factor receptor tyrosine kinase inhibitors for non-small cell lung cancer. World J Clin Oncol 2014; 5:646-59. [CrossRef]

7. Lee JK, Shin JY, Kim S, Lee S, Park C, Kim JY. Primary resistance to epidermal growth factor receptor (EGFR) tyrosine kinase inhibitors (TKls) in patients with non-smallcell lung cancer harbouring TKI-sensitive EGFR mutations: an exploratory study. Ann Oncol 2013; 24:2080-7. [CrossRef]

8. Suda K, Murakami I, Sakai K, Mizuuchi H, Shimizu S, Sato $K$, et al. Small cell lung cancer transformation and T790M mutation: complimentary roles in acquired resistance to kinase inhibitors in lung cancer. Sci Rep 2015; 5:14447. [CrossRef]

9. Li D, Ambrogio L, Shimamura T, Kubo S, Takahashi M, Chirieac LR, et al. BIBW2992, an irreversible EGFR/HER2 inhibitor highly effective in preclinical lung cancer models. Oncogene 2008; 27:4702-11. [CrossRef]

10. Engelman JA, Zejnullahu K, Gale CM, Lifshits E, Gonzales AJ, Shimamura T, et al. PF00299804, an irreversible pan-ERBB inhibitor, is effective in lung cancer models with EGFR and ERBB2 mutations that are resistant to gefitinib. Cancer Res 2007; 67:1 1924-32. [CrossRef]

11. Miller VA, Hirsh V, Cadranel J, Chen YM, Park K, Kim $\mathrm{SW}$, et al. Afatinib versus placebo for patients with advanced, metastatic non-small-cell lung cancer after failure of erlotinib, gefitinib, or both, and one or two lines of chemotherapy (LUX-Lung 1): a phase $2 \mathrm{~b} / 3$ randomised trial. Lancet Oncol 2012; 13:528-38. [CrossRef]
12. Jackman D, Pao W, Riely GJ, Engelman JA, Kris M, Janne PA, et al. Clinical definition of acquired resistance to epidermal growth factor receptor tyrosine kinase inhibitors in non-small-cell lung cancer. J Clin Oncol 2009; 28:357-60. [CrossRef]

13. Huang L, Liwu F. Mechanisms of resistance to EGFR tyrosine kinase inhibitors. Acta Pharm Sin B 2015; 5:390401. [CrossRef]

14. Levin PA, Mayer M, Hoskin S, Sailors J, Oliver DH, Gerber DE. Histologic transformation from adenocarcinoma to squamous cell carcinoma as a mechanism of resistance to EGFR inhibition. J Thorac Oncol 2015; 10:e86-8. [CrossRef]

15. Popat S, Wotherspoon A, Nutting CM, Gonzalez D, Nicholson AG, O'Brien M. Transformation to "high grade" neuroendocrine carcinoma as an acquired drug resistance mechanism in EGFR-mutant lung adenocarcinoma. Lung Cancer 2013; 80:1-4. [CrossRef]

16. National Comprehensive Cancer Network clinical practice guidelines in oncology. Small cell lung cancer. Available

at

https://www.nccn.org/professionals/physician_gls/pdf/scl c.pdf. Accessed April 10, 2017

17. Watanabe S, Sone T, Matsui T, Yamamura K, Tani M, Okazaki $A$, et al. Transformation to small-cell lung cancer following treatment with EGFR tyrosine kinase inhibitors in a patient with lung adenocarcinoma. Lung Cancer 2013; 82:370-2. [CrossRef]

18. Tatematsu A, Shimizu J, Murakami Y, Horio Y, Nakamura S, Hida T, et al. Epidermal growth factor receptor mutations in small cell lung cancer. Clin Cancer Res 2008; 14:6092-6. [CrossRef]

19. Sequist LV, Waltman BA, Dias Santagata D, Digumarthy $S$, Turke $A B$, Fidias $P$, et al. Genotypic and histological evolution of lung cancers acquiring resistance to EGFR inhibitors. Sci Transl Med 201 1; 3:75ra26. [CrossRef] 